
International

Ethics 



\section{International Ethics}

A Philosophy \& Public Affairs Reader

Edited by Charles R. Beitz, Marshall Cohen,

Thomas Scanlon, and A. John Simmons

Contributors

LAWRENCE A. ALEXANDER

CHARLES R. BEITZ

MARSHALL COHEN

ROBERT K. FULLINWIDER

GREGORY S. KAVKA

DOUGLAS P. LACKEY

DAVID LUBAN

GEORGE I. MAVRODES

THOMAS NAGEL

ONORA O'NEILL

PETER SINGER

MICHAEL WALZER

Princeton University Press

Princeton, New Jersey 
Published by

Princeton University Press,

4 I William Street,

Princeton, New Jersey 08540

In the United Kingdom:

Princeton University Press,

Chichester, West Sussex

Copyright (C) 1985 by

Princeton University Press

\section{All Rights Reseaved}

First Princeton Paperback

printing, 1985

First hardcover printing, 1985

Fourth printing, $199^{\circ}$

9

LCC: $84-42938$

ISBN: 0-69I-07683-9 (cloth)

ISBN: $0-691-02234-8$ (paper)

Princeton University Press

books are printed on acid-free

paper, and meet the guide-

lines for permanence and durability of the Committee on Production Guidelines for Book Longevity of the Council on Library Resources

Printed in the United States of America
Most of the essays in this book appeared originally in the quarterly journal Philosophy \& Public Affairs, published by Princeton University Press. Some essays include minor corrections.

Marshall Cohen, "Moral Skepticism and International Relations," PEPA I3, no. 4 (Fall I984), copyright $\mathbb{C} 1984$ by Princeton University Press; Thomas Nagel, "War and Massacre," PEPA I, no. 2 (Winter 1972 ), copyright $(\mathcal{C} 1972$ by Princeton University Press; George I. Mavrodes, "Conventions and the Morality of War," PEPA 4 , no. 2 (Winter 1975), copyright (C) 1975 by Princeton University Press; Robert K. Fullinwider, "War and Innocence," PGPA 5, no. I (Fall 1975), copyright (C) 1975 by Princeton University Press; Lawrence A. Alexander, "Self-Defense and the Killing of Noncombatants: A Reply to Fullinwider," PEPA 5, no. 4 (Summer 1976), copyright $\mathcal{C} 1976$ by Princeton University Press; Douglas P. Lackey, "Missiles and Morals: A Utilitarian Look at Nuclear Deterrence," PGPA I1, no. 3 (Summer 1982), copyright (C) 1982 by Princeton University Press; Gregory S.

Kavka, "Doubts About Unilateral Disarmament," PEPA 12, no. 3 (Summer 1983), copyright (C) 1983 by Princeton University Press; Douglas P. Lackey, "Disarmament Revisited: A Reply to Kavka and Hardin," PGPA 12, no. 3 (Summer I983), copyright (C) $\mathrm{I}_{98} 3$ by Princeton University Press; Michael Walzer, excerpts from Just and Unjust Wars, pp. 51-63, 86-101, 106-108, 33942. Copyright (C) 1977 by Basic Books, Inc., Publishers. Reprinted by permission of the publisher. David Luban, "Just War and Human Rights," PEPA 9, no. 2 (Winter 1980), copyright (C) 1980 by Princeton University Press; Michael Walzer, "The Moral Standing of States: A Response to Four Critics," PEPA 9, no. 3 (Spring 1980), copyright (C) 1980 by Princeton University Press; David Luban, "The Romance of the Nation-State," PGPA 9, no. 4 (Summer I980), copyright $C$ I 980 by Princeton University Press; Peter Singer, "Famine, Affluence, and Morality," PGPA 1, no. 3 (Spring 1972), copyright (C) 1972 by Princeton University Press; Onora O'Neill, "Lifeboat Earth," PEPA 4, no. 3 (Spring 1975), copyright $\mathcal{O} 1975$ by Princeton University Press; Charles R. Beitz, "Justice and International Relations," PEPA 4, no. 4 (Summer 1975), copyright $\mathcal{O} 1975$ by Princeton University Press. 